\title{
Uji Karakteristik Biodiesel yang dihasilkan dari Minyak Goreng Bekas Menggunakan Katalis Zeolit Alam (H-Zeolit) dan KOH
}

\author{
Isalmi Aziz, Siti Nurbayti, Arif Rahman Hakim \\ Program Studi Kimia, Fakultas Sains dan Teknologi \\ UIN Syarif Hidayatullah Jakarta \\ emi_uin@yahoo.co.id
}

\begin{abstract}
Abstrak
Penelitian ini bertujuan untuk mengetahui karaketristik biodiesel yang dihasilkan dari minyak goreng bekas menggunakan katalis $\mathrm{H}-Z$ eolit dan $\mathrm{KOH}$. Biodiesel dibuat dengan mereaksikan minyak goreng bekas dan metanol dalam perbandingan $4: 1$ (volum) dan suhu $60{ }^{\circ} \mathrm{C}$. Biodiesel yang dihasilkan dengan menggunakan katalis $\mathrm{KOH}$ mempunyai densitas $0,85 \mathrm{~g} / \mathrm{mL}$ dan viskositas 3,09 cSt. Senyawa kimia yang dominan dalam biodiesel adalah metil heksadekanoat (29.90\% area), 9-octadecenoic acid (Z)-metil ester $(55.80 \%$ area). Sedangkan biodiesel yang menggunakan katalis H-zeolit mempunyai densitas $0,78 \mathrm{~g} / \mathrm{mL}$ dan viskositas $0,35 \mathrm{cSt}$. Senyawa kimianya adalah metil heksadekanoat $(10,85 \%$ area) dan 9-octanoic acid (Z)-metil ester (11,97\% area). Biodiesel menggunakan katalis $\mathrm{KOH}$ memenuhi syarat kualitas biodiesel menurut SNI.
\end{abstract}

Keyword : Biodiesel, Minyak goreng bekas, KOH, H-zeolit

\begin{abstract}
This study was conducted to determine biodiesel characteristic produced from used cooking oil with the use of $\mathrm{H}$-zeolite and $\mathrm{KOH}$ as catalyst. Production of biodiesel had been done by treating used cooking oil and methanol in the ratio of $4: 1$ (volume) and temperature of $60{ }^{\circ} \mathrm{C}$. Biodiesel produced with the use of $\mathrm{KOH}$ catalyst has a density of $0.85 \mathrm{~g} / \mathrm{mL}$ and a viscosity of $3.09 \mathrm{cSt}$. The dominant chemical compounds in biodiesel is hexadecanoic acid, methyl ester (29.90\% area), 9-octadecenoic acid (Z) -, methyl ester (55.80\% area). While biodiesel produced by H-zeolite catalyst has a density of $0.78 \mathrm{~g} / \mathrm{mL}$ and a viscosity of $0.35 \mathrm{cSt}$. Chemical compounds were hexadecanoic acid, methyl ester (10.85\% area), 9-octanoic acid (Z) - methyl ester (11.97\% area). Biodiesel produced with the use of $\mathrm{KOH}$ as catalyst meet quality standard of SNI.
\end{abstract}

Keyword : Biodiesel, Used Cooking Oil, KOH, H-zeolite

\section{PENDAhUluAN}

Biodiesel merupakan salah satu energi alternatif yang cukup menjanjikan. Bahan bakunya yang berasal dari bahan terbarukan menjadikan ketersediaannya dapat dijamin. Biodiesel juga merupakan bahan bakar yang ramah lingkungan, tidak mengandung belerang sehingga dapat mengurangi kerusakan lingkungan yang diakibatkan oleh hujan asam (rain acid) (Suwarso et al. 2008).

Salah satu kendala yang dihadapi dalam penggunaan biodiesel sekarang ini adalah harganya yang lebih mahal dari bahan bakar diesel. Untuk itu diperlukan cara untuk menekan biaya produksi biodiesel. Salah satu cara yang dapat dilakukan adalah menggunakan bahan baku yang berasal dari minyak goreng bekas. Minyak ini secara ekonomis sudah tidak diperhitungkan lagi dan cenderung dibuang sebagai limbah karena selain merusak citra makanan yang diolah juga dapat merusak kesehatan manusia. Pemanfaatan minyak goreng bekas untuk pembuatan biodiesel akan memberikan beberapa keuntungan, diantaranya : dapat mereduksi limbah rumah tangga atau industri makanan dan mereduksi biaya produksi biodiesel sehingga harganya lebih murah dibanding dengan menggunakan minyak nabati murni. 


\begin{tabular}{|c|c|c|c|c|c|c|}
\hline \multirow{3}{*}{$3 \mathrm{R}^{\prime} \mathrm{OH}$} & \multirow{3}{*}{+} & \multirow{3}{*}{$\begin{array}{l}\mathrm{CH}_{2}-\mathrm{O}-\mathrm{COR}_{1} \\
\mathrm{l} \\
\mathrm{CH}-\mathrm{O}-\mathrm{COR}_{2} \\
\mathrm{I}_{\mathrm{CH}}-\mathrm{O}-\mathrm{COR}_{3}\end{array}$} & \multirow{3}{*}{$\stackrel{\text { katalis }}{\longleftrightarrow}$} & \multirow{2}{*}{$\begin{array}{l}\mathrm{R}_{1} \mathrm{COOR}^{\prime} \\
\mathrm{R}_{2} \mathrm{COOR}^{\prime}\end{array}$} & \multirow{2}{*}{\multicolumn{2}{|c|}{$\begin{array}{r}\mathrm{CH}_{2} \mathrm{OH} \\
+\quad \begin{array}{l}\mathrm{I} \\
\mathrm{I}\end{array}\end{array}$}} \\
\hline & & & & & & \\
\hline & & & & $\mathrm{R}_{3} \mathrm{COOR}^{\prime}$ & & $\mathrm{CH}_{2} \mathrm{OH}$ \\
\hline & & Trigliserida & & Biodiesel & & \\
\hline
\end{tabular}

Gambar 1. Reaksi Transesterifikasi

\begin{abstract}
Biodiesel dibuat melalui reaksi esterifikasi/transesterifikasi minyak/lemak dengan alkohol rantai pendek dengan bantuan katalis (Darnoko dan Cheriyan, 2000). Reaksi yang terjadi adalah terlihat pada gambar 1 .

Proses pembuatan biodiesel selama ini
\end{abstract} lebih banyak menggunakan katalis homogen, seperti KOH. Penggunaan katalis homogen ini menimbulkan permasalahan pada produk yang dihasilkan. Biodiesel yang dihasilkan masih mengandung katalis sehingga harus dilakukan separasi lagi. Selain itu penggunaan katalis $\mathrm{KOH}$ juga dapat menimbulkan reaksi samping yaitu reaksi penyabunan sehingga mempengaruhi proses pembuatan biodiesel (Aziz, 2008). Selain katalis homogen dapat juga digunakan katalis heterogen seperti H-zeolit. Keuntungan penggunaan $\mathrm{H}$-zeolit adalah proses pemurnian biodiesel lebih mudah, pemisahan katalis hanya dengan penyaringan saja (Susilowati, 2006).

Zeolit adalah mineral dengan struktur kristal alumina silikat yang berbentuk framework (struktur tiga dimensi) dan mempunyai rongga serta saluran yang diisi oleh kation logam alkali atau alkali tanah serta molekul air. Ion logam dan molekul air dapat digantikan oleh ion atau molekul lain secara reversible tanpa merusak struktur zeolit, sehingga zeolit dapat berfungsi sebagai adsorben, ion exchange dan katalis (Las, et al, 2012). Fungsi zeolit sebagai katalis disebabkan karena zeolit mempunyai pori. Semakin besar ukuran pori zeolit maka proses katalisasi akan semakin cepat. Jenis mineral zeolit yang sering ditemukan di Indonesia adalah klinoptilolit dan modernit. Salah satu daerah penghasil zeolit adalah Lampung. Zeolit yang terdapat di Lampung merupakan jenis klinoptilolit dengan rumus $\mathrm{Na}_{6}\left[\mathrm{Al}_{6} \mathrm{Si}_{30} \mathrm{O}_{72}\right]_{24}$ $\mathrm{H}_{2} \mathrm{O}$ dan berwarna putih. Densitas 1,9942$2,1781 \mathrm{~g} / \mathrm{mL}$, volume pori total $86,26 \times 10^{-3}$ dengan luas permukaan $38,93 \mathrm{~m}^{2}$ (Las, 1989).

\section{METODE PENELITIAN}

\section{Waktu dan Tempat Penelitian}

Penelitian ini berlangsung dari bulan Juli sampai Oktober 2011 bertempat di Pusat Laboratorium Terpadu UIN Syarif Hidayatullah Jakarta.

\section{Alat dan Bahan.}

Alat yang digunakan dalam penelitian ini adalah GCMS, falling ball viscosimeter, piknometer, labu leher tiga, pengaduk, termometer dan kondensor. Bahan yang digunakan adalah minyak goreng bekas (diambil dari pedagang kaki lima di sekitar kampus UIN Syarif Hidayatullah Jakarta), metanol dan zeolit alam. Zeolit ini diperoleh dari CV.Winatama Mineral Perdana di Desa Kalianda Lampung. Zeolit ini berwarna puth dengan jenis klinoptilolit.

\section{Pembuatan katalis H-zeolit dari zeolit alam}

Sebanyak 25 gram zeolit alam dimasukan ke dalam beaker glass yang berisi $125 \mathrm{~mL} \mathrm{HCl} 6 \mathrm{~N}$, diamkan selama 30 menit pada temperatur $50{ }^{0} \mathrm{C}$ sambil diaduk dengan pengaduk magnet, kemudian disaring dengan ukuran 70 mesh dan dicuci berulang kali sampai tidak ada ion $\mathrm{Cl}^{-}$yang terdeteksi oleh larutan $\mathrm{AgNO}_{3}$, dikeringkan pada suhu $130{ }^{\circ} \mathrm{C}$ selama 3 jam dalam oven ( Trisunaryanti, W. dkk, 2005).

\section{Pembuatan Biodiesel}

Katalis $\quad 1 \% \quad(\mathrm{KOH} \quad / \quad$ H-Zeolit $)$ dicampurkan dengan metanol $(100 \mathrm{~mL})$ dan dipanaskan pada suhu $60{ }^{\circ} \mathrm{C}$. Minyak goreng bekas $(400 \mathrm{~mL})$ juga dipanaskan pada suhu 60 ${ }^{\mathrm{O}} \mathrm{C}$ dalam labu leher tiga yang sudah dilengkapi dengan termometer dan pengaduk. Setelah suhu kedua reaktan tercapai $\left(60^{\circ} \mathrm{C}\right)$ larutan katalis dan metanol dimasukkan kedalam labu leher tiga, pengaduk dijalankan dengan kecepatan putaran 
1000 rpm. Produk yang dihasilkan dipisahkan dalam corong pisah selama 1 malam sampai terbentuk 2 lapisan. Lapisan atas biodiesel dan lapisan bawah gliserol. Lapisan biodiesel di uji sifat fisik dan kimianya meliputi : analisa komposisi kimianya dengan GCMS, densitas dan viskositasnya.

\section{Analisa Komposisi Senyawa dalam Biodiesel dengan GCMS}

Sampel sebanyak $1 \mu \mathrm{L}$ diinjeksikan ke dalam kolom GC dengan menggunakan kolom autosampler. Pemisahan dilakukan dalam kolom RTx 1-Ms Restech, 30 m x 0,25 mm ID, 0.25 $\mu \mathrm{m}$, dengan fase diam Poly di metyl xiloxane, suhu injektor $280^{\circ} \mathrm{C}$, suhu kolom $70^{\circ} \mathrm{C}$ dinaikkan sampai $300^{\circ} \mathrm{C}$ dengan kenaikan $10^{\circ} \mathrm{C} /$ menit, laju alir $1,15 \mathrm{~mL} / \mathrm{menit}$. Hasil analisi berupa spektrum massa dibandingkan dengan library software GCMS postrum analysis (Hermanto, 2010).

\section{Analisa Kadar Air}

Cawan porselen dikeringkan dalam oven selama 15 menit, lalu dimasukkan ke dalam desikator. Sebanyak 5 gram sampel minyak $\left(\mathrm{W}_{1}\right)$ dimasukan kedalam cawan tersebut dan ditimbang $\left(\mathrm{W}_{2}\right)$, cawan tersebut dipanaskan selama 4 jam pada suhu $110^{\circ} \mathrm{C}$. Cawan didinginkan dalam desikator dan ditimbang $\left(\mathrm{W}_{3}\right)$. Kadar air dicari dengan rumus:

Keterangan:

$$
\text { Kadar Air } \%=\frac{\mathrm{W} 2-\mathrm{W} 3}{\mathrm{~W} 1} \times 100 \%
$$

$\mathrm{W}=$ berat sampel $(\mathrm{g})$

$\mathrm{W}_{2}$ = berat cawan + sampel minyak sebelum dipanaskan $(\mathrm{g})$

$\mathrm{W}_{3}=$ berat cawan + sampel minyak setelah dipanaskan $(\mathrm{g})$

\section{Analisa densitas}

Piknometer dibersihkan dengan $\mathrm{HCl}$ lalu dibilas sebanyak 3 kali dengan aquadest, sekali dengan alkohol dan kemudian dikeringkan di dalam oven selama 5 menit. Setelah itu dimasukkan ke dalam desikator selama 10 menit, lalu ditimbang piknometer tersebut hingga diperoleh massa tetap $\left(\mathrm{W}_{1}\right)$. Piknometer diisi dengan larutan sampel, bagian luarnya dilap hingga kering dan ditimbang hingga diperoleh massa yang tetap $\left(\mathrm{W}_{2}\right)$. Perhitungan densitas $(\rho)$ sampel dengan persamaan:

Dimana : $\rho=\frac{\left(W_{2}-W_{1}\right)}{V}$

$\rho=$ densitas, $\mathrm{g} / \mathrm{mL}$

$\mathrm{W}_{2}=$ massa piknometer + sampel, $\mathrm{g}$

$\mathrm{W}_{1}=$ massa piknometer, $\mathrm{g}$

\section{Analisa Viskositas}

Alat falling ball viscometer dibersihkan dengan alkohol dan aseton lalu dibiarkan hingga mengering. Sampel minyak dimasukkan ke dalam alat tersebut secara hati-hati hingga melebihi batas titik awal $\pm 1 \mathrm{~cm}$. kemudian dimasukkan bola kaca dengan cara memiringkan alat tersebut dan ditutup dengan rapat hingga tidak ada larutan yang menetes keluar. Alat diputar $180^{\circ} \mathrm{C}$ dan stopwatch dijalankan tepat saat bola bergerak dari titik awal. Waktu yang dibutuhkan oleh bola tersebut untuk bergerak hingga garis batas akhir diukur $\left(\mathrm{t}_{0}\right)$. Viskositas sampel dihitung dengan persamaan:

\section{Keterangan:}

$$
(\mu)=k\left(\rho^{8}-\rho\right) t
$$

$\mu=$ Viskositas (mPa.s)

$\rho^{*}=$ Massa jenis bola $(\mathrm{g} / \mathrm{mL})$

$\rho=$ Massa jenis gliserol $(\mathrm{g} / \mathrm{mL})$

$\mathrm{k}=$ Koefisien bola $\left(0,007 \mathrm{mPa} . \mathrm{s} . \mathrm{cm}^{3} / \mathrm{g} . \mathrm{s}\right)$

$\mathrm{t}=$ Waktu aliran larutan (second)

\section{HASIL DAN PEMBAHASAN}

\section{Analisa Sifat Fisik dan Kimia Biodiesel dan Minyak Goreng Bekas}

Minyak goreng bekas yang digunakan dalam penelitian ini mengandung kadar air 0,2\%. Hasil ini menunjukan bahwa kadar air kurang dari $1 \%$ sehingga tidak perlu ada pelakuan untuk menghilangkan kadar air. Kadar air yang tinggi (lebih dari 1\%) dapat mengakibatkan reaksi samping yaitu reaksi hidrolisis yang dapat mengganggu reaksi pembentukan biodiesel. Kadar air yang terkandung dalam minyak goreng selain berasal dari air yang terkandung minyak goreng itu sendiri, juga berasal dari bahan pangan lain yang digoreng. Selama proses penggorengan berlangsung, sebagian air akan bebas menguap dan sebagian lagi masih berada dalam minyak (Sugiati, 2007). 
Tabel 1. Sifat fisik biodiesel dengan katalis $\mathrm{KOH}$ dan H-zeolit

\begin{tabular}{lccccc}
\hline No & Sifat Fisik & $\begin{array}{c}\text { Minyak } \\
\text { Goreng Bekas }\end{array}$ & $\begin{array}{c}\text { Katalis } \\
\text { KOH }\end{array}$ & $\begin{array}{c}\text { Katalis } \\
\text { zeolit }\end{array}$ & $\begin{array}{c}\text { Biodiesel } \\
\text { SNI 2006 }\end{array}$ \\
\hline $\mathbf{1}$ & Densitas $40^{\circ} \mathrm{C}(\mathrm{g} / \mathrm{mL})$ & 0,88 & 0,85 & 0,78 & $0,85-0,89$ \\
$\mathbf{2}$ & Viskositas $40^{\circ} \mathrm{C}(\mathrm{cSt})$ & 3,27 & 3,09 & 0,35 & $2,3-6,0$ \\
\hline
\end{tabular}

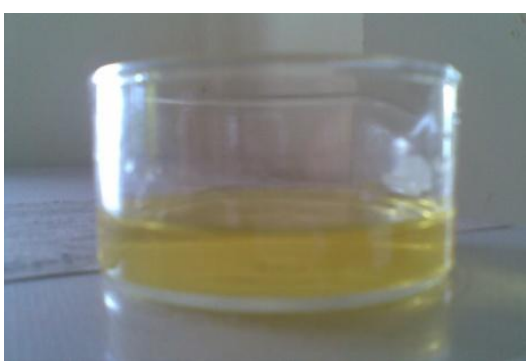

(a)

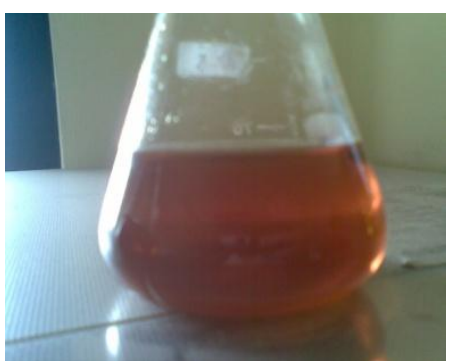

(b)

Gambar 2 . Biodiesel dengan katalis H-zeolit (a) dan $\mathrm{KOH}$ (b)

Tabel 2. Komposisi senyawa dalam biodiesel dengan katalis H-zeolit

\begin{tabular}{|c|c|c|c|c|}
\hline Puncak & $\begin{array}{c}\text { Luas } \\
\text { Puncak } \\
(\%)\end{array}$ & $\begin{array}{l}\text { Waktu } \\
\text { Retensi }\end{array}$ & Nama Senyawa & $\begin{array}{c}\text { Rumus } \\
\text { Molekul }\end{array}$ \\
\hline 1 & 0.59 & 3.209 & Heptanoic acid, metil ester & $\mathrm{C}_{8} \mathrm{H}_{16} \mathrm{O}_{2}$ \\
\hline 2 & 0.65 & 3.758 & Heptanoic acid & $\mathrm{C}_{7} \mathrm{H}_{14} \mathrm{O}_{2}$ \\
\hline 3 & 0.35 & 4.374 & 2,4-dimethyl-4-octanol & $\mathrm{C}_{10} \mathrm{H}_{22} \mathrm{O}$ \\
\hline 4 & 1.10 & 4.584 & Octanoic acid, metil ester & $\mathrm{C}_{9} \mathrm{H}_{18} \mathrm{O}_{2}$ \\
\hline 5 & 1.27 & 5.166 & Octanoic acid & $\mathrm{C}_{8} \mathrm{H}_{16} \mathrm{O}_{2}$ \\
\hline 6 & 0.83 & 6.034 & Nonanoic acid, metil ester & $\mathrm{C}_{10} \mathrm{H}_{20} \mathrm{O}_{2}$ \\
\hline 7 & 1.21 & 6.586 & Nonanoic acid & $\mathrm{C}_{9} \mathrm{H}_{18} \mathrm{O}_{2}$ \\
\hline 8 & 0.69 & 7.399 & 2,4-decadienal, (E,E) & $\mathrm{C}_{10} \mathrm{H}_{16} \mathrm{O}$ \\
\hline 9 & 0.95 & 9.062 & Octanedioic acid, dimetil ester & $\mathrm{C}_{10} \mathrm{H}_{18} \mathrm{O}_{4}$ \\
\hline 10 & 0.43 & 10.069 & Hexadecanoic acid, metil ester & $\mathrm{C}_{17} \mathrm{H}_{34} \mathrm{O}_{2}$ \\
\hline 11 & 1.12 & 10.329 & Nonanedioic acid, dimetil ester & $\mathrm{C}_{11} \mathrm{H}_{20} \mathrm{O}_{4}$ \\
\hline 12 & 0.77 & 10.932 & Dodecane, 1,1-dimethoxi & $\mathrm{C}_{14} \mathrm{H}_{30} \mathrm{O}_{2}$ \\
\hline 13 & 0.67 & 12.414 & Tetradecanoic acid, metil ester & $\mathrm{C}_{15} \mathrm{H}_{30} \mathrm{O}_{2}$ \\
\hline 14 & 1.59 & 14.309 & $\begin{array}{l}\text { 9-hexadecanoic acid, metil ester } \\
\text { (Z) }\end{array}$ & $\mathrm{C}_{17} \mathrm{H}_{32} \mathrm{O}_{2}$ \\
\hline 15 & 10.85 & 14.531 & Hexadecanoic acid, metil ester & $\mathrm{C}_{17} \mathrm{H}_{34} \mathrm{O}_{2}$ \\
\hline 16 & 19.85 & 14.858 & Heptadecanoic acid & $\mathrm{C}_{16} \mathrm{H}_{32} \mathrm{O}_{2}$ \\
\hline 17 & 4.53 & 16.340 & $\begin{array}{l}\text { 9,12-octadecanoic } \operatorname{acid}(\mathrm{Z}, \mathrm{Z}) \\
\text { metil ester }\end{array}$ & $\mathrm{C}_{19} \mathrm{H}_{34} \mathrm{O}_{2}$ \\
\hline 18 & 11.97 & 16.431 & 9-octanoic acid (Z),- metil ester & $\mathrm{C}_{19} \mathrm{H}_{36} \mathrm{O}_{2}$ \\
\hline 19 & 6.14 & 16.782 & $\begin{array}{l}\text { 9,12-octadecanoic acid, metil } \\
\text { ester }\end{array}$ & $\mathrm{C}_{19} \mathrm{H}_{34} \mathrm{O}_{2}$ \\
\hline 20 & 31.59 & 16.868 & 9-octadecanoic acid (Z)- & $\mathrm{C}_{18} \mathrm{H}_{34} \mathrm{O}_{2}$ \\
\hline 21 & 1.28 & 17.368 & Octadecanamide & $\mathrm{C}_{18} \mathrm{H}_{37} \mathrm{NO}$ \\
\hline 22 & 1.58 & 21.807 & Bis(2-etilhexil)phthalate & $\mathrm{C}_{16} \mathrm{H}_{22} \mathrm{O}_{4}$ \\
\hline
\end{tabular}




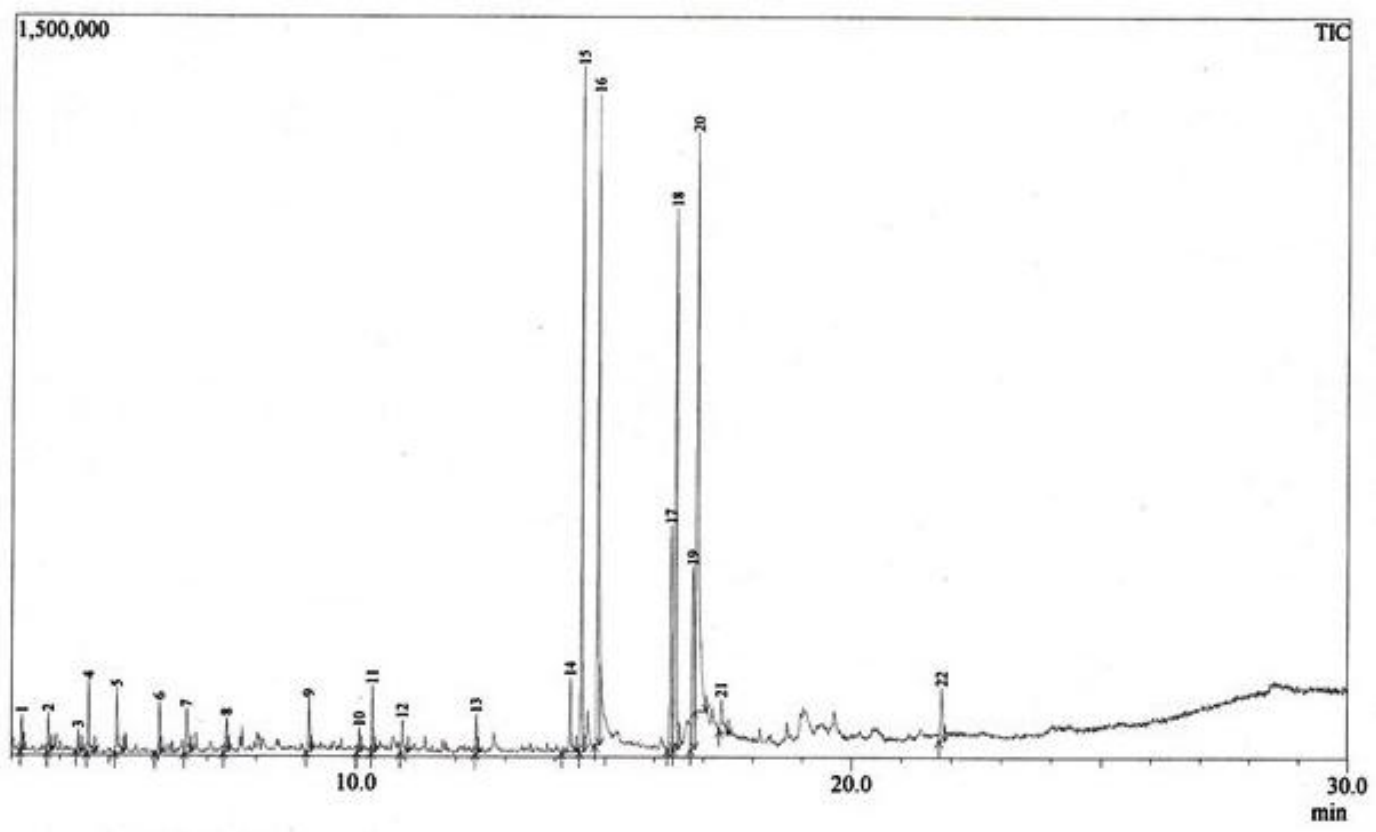

Gambar 3. Kromatogram biodiesel hasil analisa GCMS dengan katalis zeolit

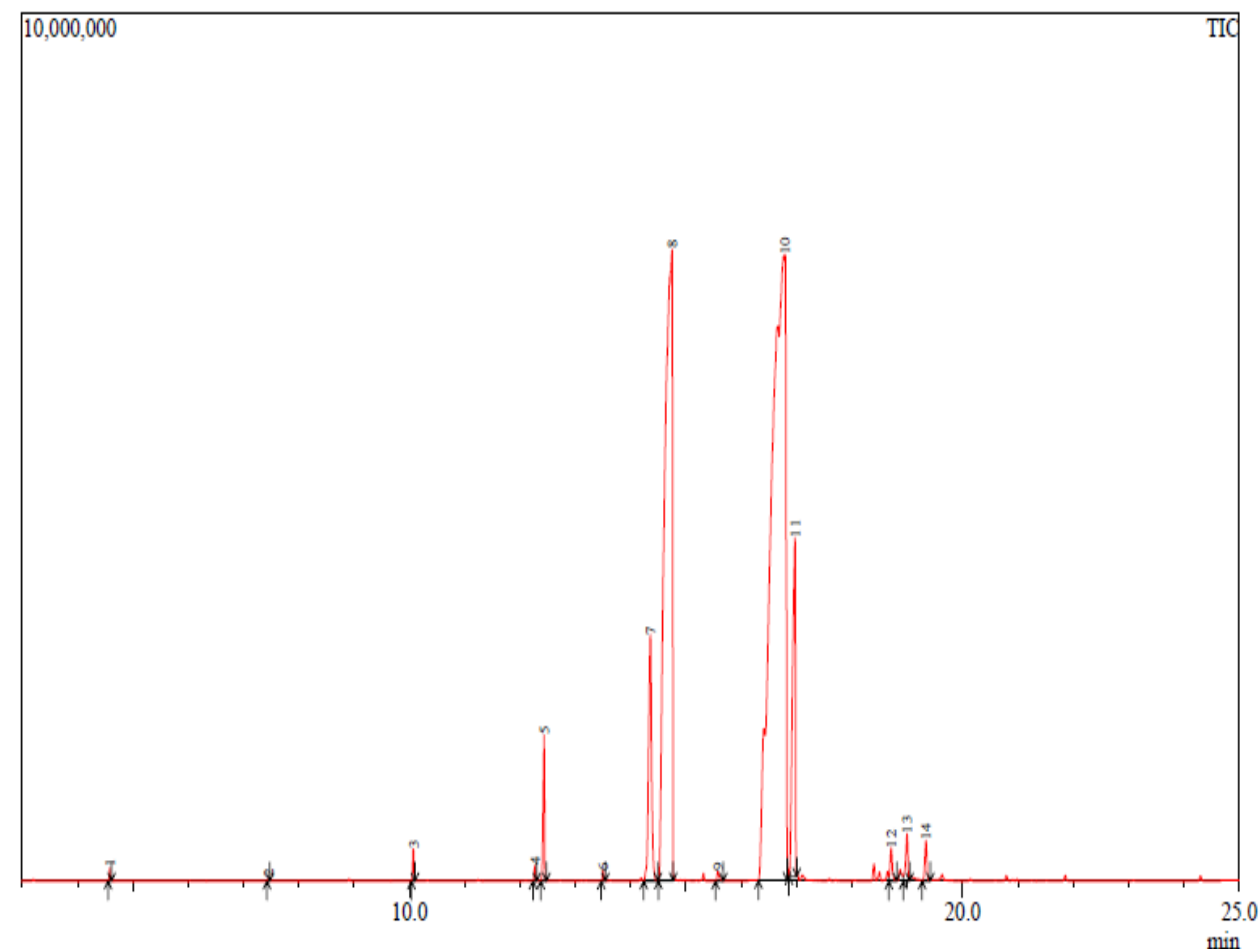

Gambar 4. Kromatogram biodiesel hasil analisa GCMS dengan katalis KOH 
Tabel 3. Jenis senyawa yang terkandung pada biodiesel dengan katalis $\mathrm{KOH}$

\begin{tabular}{ccclc}
\hline Puncak & $\begin{array}{c}\text { Luas } \\
\text { Puncak } \\
(\mathbf{\%})\end{array}$ & $\begin{array}{c}\text { Waktu } \\
\text { Retensi }\end{array}$ & \multicolumn{1}{c}{ Nama Senyawa } & $\begin{array}{c}\text { Rumus } \\
\text { Molekul }\end{array}$ \\
\hline $\mathbf{1}$ & 0.09 & 4.583 & Octanoic acid, metil ester & $\mathrm{C}_{9} \mathrm{H}_{18} \mathrm{O}_{2}$ \\
$\mathbf{2}$ & 0.02 & 7.449 & Decanoic acid, metil ester & $\mathrm{C}_{12} \mathrm{H}_{24} \mathrm{O}_{2}$ \\
$\mathbf{3}$ & 0.25 & 10.070 & Dodecanoic acid, metil ester & $\mathrm{C}_{13} \mathrm{H}_{26} \mathrm{O}_{2}$ \\
$\mathbf{4}$ & 0.11 & 12.266 & Metil ricinoleat & $\mathrm{C}_{19} \mathrm{H}_{36} \mathrm{O}_{2}$ \\
$\mathbf{5}$ & 1.27 & 12.432 & Tetradecanoic acid, metil ester & $\mathrm{C}_{15} \mathrm{H}_{30} \mathrm{O}_{2}$ \\
$\mathbf{6}$ & 0.08 & 13.500 & Pentadecanoic acid, metil ester & $\mathrm{C}_{16} \mathrm{H}_{32} \mathrm{O}_{2}$ \\
$\mathbf{7}$ & 4.58 & 14.355 & 9-Hexadecenoic acid, metil ester, (Z)- & $\mathrm{C}_{17} \mathrm{H}_{32} \mathrm{O}_{2}$ \\
$\mathbf{8}$ & 29.90 & 14.750 & Hexadecanoic acid, metil ester & $\mathrm{C}_{17} \mathrm{H}_{34} \mathrm{O}_{2}$ \\
$\mathbf{9}$ & 0.14 & 15.576 & Heptadecanoic acid, metil ester & $\mathrm{C}_{18} \mathrm{H}_{36} \mathrm{O}_{2}$ \\
$\mathbf{1 0}$ & 55.80 & 16.783 & 9-Octadecenoic acid (Z)-, metil ester & $\mathrm{C}_{19} \mathrm{H}_{34} \mathrm{O}_{2}$ \\
$\mathbf{1 1}$ & 6.17 & 16.967 & Octadecanoic acid, metil ester & $\mathrm{C}_{19} \mathrm{H}_{38} \mathrm{O}_{2}$ \\
$\mathbf{1 2}$ & 0.44 & 18.708 & Oxiraneoctanoic acid, 3-octil-, metil ester & $\mathrm{C}_{19} \mathrm{H}_{36} \mathrm{O}_{3}$ \\
$\mathbf{1 3}$ & 0.66 & 18.993 & 11-Eicosenoic acid, metil ester & $\mathrm{C}_{21} \mathrm{H}_{40} \mathrm{O}_{2}$ \\
$\mathbf{1 4}$ & 0.49 & 19.355 & Eicosanoic acid, metil ester & $\mathrm{C}_{21} \mathrm{H}_{42} \mathrm{O}_{2}$ \\
\hline
\end{tabular}

Pada dasarnya kadar air berpengaruh terhadap perlakuan produksi biodiesel. Menurut Rahayu (2009) syarat maksimal kadar air pada minyak adalah $1 \%$. Jika kadar air lebih dari $1 \%$ maka perlu adanya perlakuan lebih lanjut untuk menghilangkan kadar air yang terkandung dalam minyak. Yoeswono (2008) mengurangi kadar air yang terkandung pada minyak dengan menambahkan natrium anhidrat.

Kadar asam lemak bebas (FFA) yang dihasilkan adalah $2,71 \mathrm{mg} \mathrm{KOH} / \mathrm{g}$.minyak atau $0,07 \%$. Nilai ini lebih kecil dari batas yang ditetapkan yaitu maksimal 1\%. Jika kadar FFA < $1 \%$ maka tidak diperlukan pretreatment (esterifikasi) untuk menghilangkan FFA (Rahayu, 2009). Jadi pembuatan biodiesel bisa langsung menggunakan proses transesterifikasi tanpa melalui esterifikasi.

Nilai densitas dan viskositas pada penelitian ini diukur pada suhu $40{ }^{\circ} \mathrm{C}$. Nilai densitas minyak goreng bekas yang digunakan adalah $0,88 \mathrm{~g} / \mathrm{mL}$ dan viskositas 3,27 cSt. Jika dibandingkan dengan biodiesel, densitas dan viskositas minyak goreng bekas lebih besar (Tabel 1). Hal ini disebabkan karena pada saat terjadi reaksi transesterifikasi terjadi pemutusan rantai gliserol yang menyebabkan densitas dan viskositas biodiesel menjadi rendah.
Densitas biodiesel yang menggunakan katalis $\mathrm{KOH}$ lebih besar dibandingkan yang menggunakan katalis H-zeolit. Hal ini disebabkan senyawa biodiesel yang dihasilkan juga berbeda. Biodiesel dengan $\mathrm{KOH}$ sebagian besar sudah merupakan senyawa ester sedangkan yang menggunakan zeolit alam sebagian besar masih berupa asam belum terkonversi menjadi ester. Biodiesel yang menggunakan $\mathrm{KOH}$ memenuhi SNI Biodiesel sedangkan biodiesel dengan zeolit tidak, lebih rendah dibandingkan SNI. Begitu juga dengan viskositasnya. Biodiesel dengan $\mathrm{KOH}$ juga memenuhi SNI Biodiesel.

Dari segi warna, biodiesel dengan menggunakan katalis H-zeolit lebih bagus dibandingkan yang menggunakan katalis $\mathrm{KOH}$. Perbandingannya dapat dilihat pada gambar 2 .

Biodiesel dengan katalis H-zeolit lebih jernih dibandingkan dengan katalis $\mathrm{KOH}$. Ini disebabkan karena H-zeolit yang berfungsi sebagai katalis juga dapat berfungsi sebagai adsorben. H-zeolit dapat mengadsorbsi senyawa pengotor yang terdapat dalam biodiesel sehingga warna biodiesel yang dihasilkan semakin bagus.

\section{Komposisi Senyawa Biodiesel dengan GCMS}

Analisa dengan GCMS digunakan untuk mengetahui jenis senyawa yang terkandung di dalam biodiesel yang dihasilkan. Analisis ini 
menghasilkan puncak-puncak spektra yang masing-masing menunjukkan jenis metil ester yang spesifik. Hasil analisa GCMS dapat dilihat pada tabel 2 dan 3.

Biodiesel yang menggunakan katalis $\mathrm{H}$ zeolit mengandung senyawa yang terbesar adalah 9-octadecanoic acid (31,59\% area) dan heptadecanoic acid (19,85\% area). Senyawa ini masih berupa asam belum terkonversi menjadi ester. Hal ini menunjukkan bahwa reaksi belum sempurna. Senyawa ester yang dihasilkan seperti yang tercantum dalam tabel 2 adalah hexadecanoic acid, metil ester $(10,85 \%$ area) dan 9-octanoic acis, metil ester (11,97\% area). Jumlahnya lebih kecil dibandingkan senyawa yang masih berupa asam.

Biodiesel yang dihasilkan dengan menggunakan katalis $\mathrm{KOH}$, senyawa yang dihasilkan umumnya sudah merupakan senyawa ester. Senyawa terbesar adalah 9-octadecenoic acid (Z)-, metil ester $(55,80 \%$ area) dan hexadecanoic acid, metil ester (29,90\% area). Hasil lengkapnya dapat dilihat pada Tabel 3 dan Gambar 4.

Biodiesel yang dihasilkan dari katalis $\mathrm{H}-$ zeolit mengandung fraksi atom $\mathrm{C}_{9-19}$, sedangkan biodiesel berkatalis $\mathrm{KOH} \quad \mathrm{C}_{9}$ dan $\mathrm{C}_{12-21}$. Perbedaan ini mungkin disebabkan karena fungsi katalis dari $\mathrm{H}$-zeolit yang juga bisa pada reaksi cracking minyak sehingga fraksi berat $\left(\mathrm{C}_{21}\right)$ dapat dipecah menjadi fraksi yang lebih ringan.

\section{KESIMPULAN DAN SARAN}

\section{Kesimpulan}

Dari penelitian yang sudah dilakukan dapat disimpulkan :

1. Densitas dan viskositas biodiesel yang menggunakan katalis $\mathrm{H}$-zeolit adalah 0,78 $\mathrm{g} / \mathrm{mL}$ dan $0,35 \mathrm{sCt}$.

2. Densitas dan viskositas biodiesel yang menggunakan katalis $\mathrm{KOH}$ adalah 0,85 $\mathrm{g} / \mathrm{mL}$ dan 3,09 sCt.

3. Senyawa ester yang dominan dalam biodiesel dengan katalis H-zeolit adalah hexadecanoic acid, metil ester $(10,85 \%$ area) dan 9-octanoic acis, metil ester (11,97\% area).

4. Senyawa ester yang dominan dalam biodiesel dengan katalis $\mathrm{KOH}$ adalah 9octadecenoic acid (Z)-, metil ester $(55,80 \%$ area) dan hexadecanoic acid, metil ester $(29,90 \%$ area).

5. Biodiesel yang menggunakan katalis $\mathrm{KOH}$ memenuhi syarat kualitas biodiesel menurut SNI.

\section{Saran}

1. Perlu dilakukan pengujian sifat fisik (titik nyala, angka cetan dll) dari biodiesel.

2. Perlu dilakukan optimasi dari pembuatan $\mathrm{H}$ zeolit.

\section{UCAPAN TERIMAKASIH}

Pada kesempatan ini penulis mengucapkan terimakasih kepada P3M Fakultas Sains dan Teknologi UIN Syarif Hidayatullah Jakarta yang telah mendanai penelitian ini.

\section{DAFTAR PUSTAKA}

1. Aziz,I., 2008, Kinetika Reaksi Transesterifikasi Minyak Goreng Bekas", Valensi, Vol.1, No.1.

2. Darnoko, D and Cheryan, M, 2000, "Kinetics of Palm Oil Transeterification in a Batch Reactor", J. Am.Oil Chem.Soc., 77, 1263-1267.

3. Ginting, A.B., Angraini, D., Indaryanti, S., Kriswarini, R., 2007, "Karakterisasi Komposisi Kimia, Luas Permukaan Pori dan Sifat Termal dari Zeolt Bayah, Tasikmalaya dan Lampung", J. Tekn. Bhn. Nukl., Vol.3.No.1, 38-48.

4. Las, T., Firdiyono, F., dan Hendrawan, A., 2012, "Adsorbsi unsur pengotor larutan natrium silikat menggunakan zeolit alam Karangnunggal" J. Valensi. Vol.2, No. 4, 368-378.

5. Las, T., 1989 "Use of Natural Zeolite for Nuclear Waste Treatment"., Departement of Chemistry and Applied Chemistry, University of Salford, The United Kingdom.

6. Rahayu, M., 2008, "Teknologi Proses Produksi Biodiesel“", www.google.com.

7. Susilowati, 2006, "Biodiesel dari Minyak Biji Kapuk dengan Katalis Zeolit“, Jurnal Teknik Kimia, Vol.1, No.1, hal 10-14.

8. Suwarsono, WP., Gani, I.Y, dan Kusyanto, 2008, "Sintesis Biodiesel dari Minyak Biji Ketapang yang Berasal dari Pohon Ketapang Yang Tumbuh di Kapus UI Depok“, Valensi, vol.1, no.2, 44-52.

9. Trisunaryanti, W., Triwahyuni, E., dan Sudiono, S., 2005,"Preparasi, modifikasi dan karaterisasi katalsi Ni-Mo/Zeolit alam dan Mo-Ni/Zeolit Alam", Jurnal Teknoin, Vol.10,N0.4, hal.269283. 